\title{
Effect of Keyword Position on Sentence Recognition under Background Noise in Mild Cognitive Impairment
}

\author{
Soo Jung Lee ${ }^{a}$, HyangHee Kim ${ }^{a, b}$ \\ ${ }^{a}$ Graduate Program in Speech and Language Pathology, Yonsei University, Seoul, Korea \\ ${ }^{b}$ Department of Rehabilitation Medicine and Research Institute of Rehabilitation Medicine, Yonsei University College of Medicine, Seoul, Korea
}

Correspondence: HyangHee Kim, $\mathrm{PhD}$ Graduate Program in Speech and Language Pathology, Yonsei University, 50-1 Yonsei-ro, Seodaemun-gu, Seoul 03722, Korea

Tel: $+82-2-2228-3900$

Fax: +82-2-2227-7984

E-mail: h.kim@yonsei.ac.kr

Received: July 4, 2016

Revised: August 1, 2016

Accepted: August 5, 2016
Objectives: As speech perception is the initial stage of auditory language comprehension, a listener's auditory, as well as cognitive functions (e.g., memory), contribute to speech perception. The aim of the present study was to explore the effect of keyword position on sentence recognition under background noise in mild cognitive impairment. Methods: We studied 14 elderly individuals with amnestic mild cognitive impairment (aMCl) as an experimental group and 14 elderly individuals with normal cognitive function as a control group. The tasks included immediate and delayed recall tests and sentence recognition tests. Results: We found that the aMCl group scored significantly lower than the normal elderly on both the immediate and delayed recall tests. Also, significant differences in word recognition scores were found only on the first keyword, not on the last. Conclusion: These results reflect the diminished primacy effect of serial position in aMCl. Also, aMCl with reduced working memory capacity may selectively store the more recently processed words and pay more attention to predicates which are regarded as major components in Korean sentence comprehension. Our findings suggest that repeating core messages or putting the keyword at the end of a sentence could be useful strategies to ensure elderly with cognitive impairment overcome speech perception and auditory comprehension difficulties they may have.

Keywords: MCl, Speech perception, Serial position effect, Working memory, Korean sentence comprehension
말소리 지각(speech perception)이란 청각적 언어 자극을 이해하 기 위해 선행되는 필수적인 언어처리과정이다(Friederici, 2012). 이 단계에서 청자는 복잡한 음향학적 말 신호들을 의미 있는 언어적 단위로 인식한다(Davis \& Johnsrude, 2007). 이러한 말소리 지각에 는 다음과 같이 청자의 청력과 인지적 능력이 함께 영향을 미친다 (Pichora-Fuller, 2006). 첫째, 음향학적 말 신호들을 원활하게 지각 하기 위해서는 청자의 말초성 청력 및 중추청각처리능력이 정상이 어야 한다. 둘째, 말소리 지각이 청각적 이해 단계로 나아가기 위해 서는 지속적으로 음향학적 신호들을 인식하는 동시에 앞서 지각한 정보를 정확하게 기억해야 한다는 점에서 청자의 인지적 능력도 중 요하게 관여한다. 특히, 청자의 내부적 요인(예: 난청) (Tun, Benich- ov, \& Wingfield, 2010)이나 외부적 요인(예: 배경 소음, 화자의 빠른 말 속도) (Rönnberg, Rudner, Lunner, \& Zekveld, 2010; Wingfield, McCoy, Peelle, Tun, \& Cox, 2006)으로 인하여 음향학적 정보가 왜 곡되거나 소실될 경우 청자의 인지적 능력이 관여하는 정도는 더욱 커진다. 이 때, 청자는 잃어버린 정보를 복구하기 위해 선행지식이 나 문맥적/의미적 단서들을 활용하여 추론하는 등 인지적 처리 과 정을 수행해야 한다. 제한된 인지적 용량(cognitive capacity)의 많 은 부분이 이러한 처리 과정에 할당되기 때문에 청자가 기억하는 정보의 양은 감소한다(Pichora-Fuller, 2006). 이러한 측면에서, 인 지장애 환자는 인지 기능이 정상인 사람에 비하여 어려운 듣기 상 황에서의 말소리 지각에 결함을 나타낼 가능성이 크다. 
경도인지장애(mild cognitive impairment, $\mathrm{MCI}$ ) 노년층은 정상 노년층에 비하여 말소리에 비해 배경 소음이 큰 상황에서 말소리 지각 능력이 특히 저하된다(Lee, Park, Kim, \& Kim, 2016). MCI는 정상적 노화와 치매의 중간 단계로, 두 가지 유형, 즉 기억력 저하가 두드러지는 건망성 경도인지장애(amnestic MCI, aMCI), 그리고 기 억력은 정상이나 다른 인지능력(예: 주의집중, 언어능력, 집행기능 등)에 결함이 있는 비건망성 경도인지장애(non-amnestic $\mathrm{MCI}$ )로 분류된다(Petersen et al., 2001). MCI 노년층을 대상으로 소음 상황 에서의 말소리 지각 능력을 살펴본 선행 연구들에서, $\mathrm{MCI}$ 는 정상 노년층에 비하여 말소리 지각 능력이 저하되거나(Aimoni et al., 2014; Gates, Anderson, Feeney, McCurry, \& Larson, 2008; Gates et al., 2010; Rahman, Mohamed, Albanouby, \& Bekhet, 2011) 유지되 는데(Idrizbegovic et al., 2011), 이러한 차이는 검사에서 적용한 소 음 크기가 서로 다르기 때문일 가능성이 있다. 신호 대 잡음비(signal-to-noise ratio, SNR)가 양수 값인 경우, 즉 목표 말소리가 배경 소음보다 큰 경우 $(\mathrm{SNR}+4 \mathrm{~dB})$ 에는 $\mathrm{MCI}$ 와 정상 노년층의 말소리 지각 능력에 차이가 없었다(Idrizbegovic et al., 2011). 한편, 목표 말 소리와 배경 소음의 크기가 같으면(SNR $0 \mathrm{~dB}$ ) 다소 상이한 연구결 과를 보였는데, $\mathrm{MCI}$ 가 정상 노년층보다 수행력이 저하되거나(Gates et al., 2008; Gates et al., 2010; Rahman et al., 2011) 동일하였다(Lee et al., 2016). 한편, SNR이 음수 값인 경우, 즉 배경 소음이 목표 말소 리보다 확연히 크면(SNR -5 dB), MCI가 정상 노년층에 비해 말소 리 지각 능력이 뚜렷하게 저하되었다(Lee et al., 2016). 선행 연구들 에서의 채점기준은 모두 목표 단어 혹은 문장 내 핵심 단어(keyword)에 대한 정/오반응이었으며, 정확하게 지각한 목표 단어의 최 종 점수만을 측정하여 말소리 지각 능력을 평가하였다.

Lee 등(2016)은 문장 지각 과제 시 SNR $0 \mathrm{~dB}$ 에서는 MCI와 정상 노년층 간에 전반적인 수행력(즉, 최종 점수) 간 차이가 없는 것으로 보고하였으나, 두 집단이 지각한 내용(즉, 옳게 지각한 핵심 단어) 에는 차이가 있을 가능성이 있다. 예컨대, "버스에 사람이 많아서 내가 앉을 자리가 없다"라는 문장을 듣고 따라말하는 과제를 시행 했을 때, 대상자 A와 B가 동일하게 3 개의 핵심 단어를 올바르게 지 각했다고 하더라도 A가 지각한 핵심 단어는 "버스", "사람", "많아 서”인 반면, B는 "앉을", "자리”, "없다”일 수 있다.

이는 '계열위치효과(serial position effect)'로 설명할 수 있는데, 기억 회상 과제 시에 나타나는 기억 책략을 의미한다(Murdock, 1962). 기억 회상 과제란 다양한 기억 평가 방법의 하나로서, 피검자 에게 일련의 단어들을 제시한 후 이 단어들을 제시된 순서에 상관 없이 최대한 많이 회상하게끔 한다. 이때, 단어 목록의 전반부나 후 반부에 제시된 항목이 중반부에 제시된 항목보다 더 잘 회상되는
현상이 계열위치효과이다. 특히, 목록의 전반부가 더 쉽게 회상되 는 현상을 초두효과(primacy effect)라고 하며, 후반부가 더 쉽게 회상되는 것을 최신효과(recency effect)라고 지칭한다(Glanzer \& Cunitz, 1966). 정상 노년층에서는 일반적으로 초두효과와 최신효 과 간의 차이가 없는 반면(Howieson et al., 2011), MCI에서 나타나 는 인지적 능력의 결함은 낮은 초두효과와 높은 최신효과로 반영된 다(Cunha, Guerreiro, de Mendonca, Oliveira, \& Santana, 2012; Howieson et al., 2011; Moser et al., 2013). 특히 기억력 결함이 두드 러지는 $\mathrm{aMCI}$ 의 경우 초두효과는 두드러지게 저하되는 반면 최신 효과는 비교적 유지된다(Howieson et al., 2011; Moser et al., 2013). 이러한 기억 책략의 차이는 말소리 지각 과정에도 반영될 가능성 이 있으며, $\mathrm{aMCI}$ 노년층은 주로 문장의 전반부에 비해 후반부에 위치한 핵심 단어를 올바르게 지각하는 반면, 정상 노년층은 문장 의 전·후반부 핵심 단어 지각에 차이가 적을 것이다.

이러한 개념을 바탕으로 설정된 본 연구의 가설은 다음과 같다. $\mathrm{aMCI}$ 노년층은 정상 노년층에 비해, 첫째, 즉각회상 및 지연회상 점수가 모두 저하되어 기억력 결함을 나타낼 것이다. 둘째, 유의하 게 낮은 점수를 보이는 핵심 단어의 위치는 문장의 전반부일 것이 다. 본 연구를 통해 $\mathrm{aMCI}$ 노년층의 말소리 지각 특성을 파악할 수 있다면, 이는 $\mathrm{aMCI}$ 와 같은 인지장애 노년층을 위한 의사소통 전략 에 반영될 수 있을 것이다. 즉, 소음 상황에서 인지장애 노년층의 말 소리 지각, 나아가 언어 이해를 촉진시키기 위하여 어떠한 보상 전 략을 세우는 것이 가능할지 논의해 볼 수 있을 것이다.

\section{연구 방법}

\section{연구 대상}

본 연구는 부산 지역에 거주하는 $\mathrm{aMCI}$ 노년층 14 명(연령 71.07 \pm 5.89 세; 교육년수 $8.36 \pm 4.94$ 년)을 실험군으로 하였다. $\mathrm{aMCI}$ 노 년층은 부산 동아대학교병원 인지장애·치매센터를 내원한 환자 로, (1) 연령이 만 60세 이상이며, (2) Petersen 등(2001)의 진단기준 을 적용하여 신경과 전문의로부터 $\mathrm{aMCI}$ 로 진단받고, (3) 치매임상 평가척도(clinical dementia rating).5에 해당하며, (4) 뇌졸중, 파킨 슨병, 두부 손상 등의 병력이 없는 환자를 대상으로 하였다.

대조군인 정상 노년층 14 명(연령 $69.14 \pm 7.47$ 세; 교육년수 $9.57 \pm$ 5.60 년)의 선정기준은, (1) 연령이 만 60세 이상이며, (2) 한국판 간이 정신상태검사(Korean Mini-Mental State Examination, K-MMSE) 의 점수가 연령 및 교육년수 규준의 -1 표준편차 이내에 해당하고 (Kang, 2006), (3) 서울언어학습검사(Seoul Verbal Learning Test, SVLT)의 점수가 연령 및 교육년수 규준의 -1 표준편차 이내에 해당 
Table 1. Demographic data and audiometric test results

\begin{tabular}{lccc}
\hline & $\begin{array}{c}\text { aMCl } \\
(\mathrm{N}=14)\end{array}$ & $\begin{array}{c}\text { Normal elderly } \\
(\mathrm{N}=14)\end{array}$ & $t$ \\
\hline Demographics & & & \\
$\quad$ Gender (male:female) & $7: 7$ & $8: 6$ & \\
Age (yr) & $71.07(5.89)$ & $69.14(7.47)$ & -.758 \\
$\quad$ Education (yr) & $8.36(4.94)$ & $9.57(5.60)$ & .609 \\
Audiometric test results & & & \\
$\quad$ Pure tone average (dB HL) & $18.13(9.46)$ & $18.04(9.85)$ & -.024 \\
Speech reception threshold (dB HL) & $20.00(7.53)$ & $19.64(8.48)$ & -.118 \\
Most comfortable loudness level (dB HL) & $53.21(6.39)$ & $53.57(6.02)$ & .152 \\
\hline
\end{tabular}

Values are presented as mean (SD). Audiometric test results were averaged across both ears.

$\mathrm{aMCl}=$ amnestic mild cognitive impairment; $\mathrm{dB}=$ decibels; $\mathrm{HL}=$ hearing level.

하며(Kang \& Na, 2003), (4) 인지 기능에 영향을 미치는 신경학적 (예: 치매, 파킨슨병, 뇌졸중, 두부 손상 등), 정신적(예: 우울증 등) 질환의 경험이 없는 자로 하였다.

청력과 관련하여 두 집단은 모두 (1) 순음청력검사(pure-tone audiometry) 상 양측 귀의 평균 청력 $(500 \mathrm{~Hz}, 1,000 \mathrm{~Hz}, 2,000 \mathrm{~Hz}$ 의 4 분법 평균)이 각각 $40 \mathrm{~dB} \mathrm{HL}$ 이내이고, (2) 양측 귀의 어음청취 역치(speech reception threshold)가 각각 $40 \mathrm{~dB} \mathrm{HL}$ 이내이며, (3) 양측 귀의 평균청력역치의 차이가 $10 \mathrm{~dB} \mathrm{HL}$ 이내이고, (4) 순음청 력검사 및 임피던스 청력검사(impedance audiometry)에서 중이의 상태가 정상이며, (5) 보청기 착용 경험이 없는 자로 선정하였다.

본 연구는 모든 연구 대상자로부터 연구 참여 동의서를 작성 받 은 후 실시하였다. 각 집단별 인구통계학적 특성 및 청력검사 결과 는 Table 1에 제시하였다.

\section{검사 과제 및 절차}

청력 검사

첫째, 임피던스 청력검사를 통하여 중이(middle ear)의 정상 여 부를 확인하였다. 임피던스 청력검사는 피검자의 외이도를 밀봉한 상태에서 외이도 내의 압력을 변화시키며 특정 주파수 및 강도의 소리에너지를 줄 때, 고막에서 반사되는 음향에너지를 측정하여 중 이의 상태를 간접적으로 평가하는 검사이다. 둘째, 순음청력검사 를 통하여 $250 \mathrm{~Hz}, 500 \mathrm{~Hz}, 1,000 \mathrm{~Hz}, 2,000 \mathrm{~Hz}, 4,000 \mathrm{~Hz}, 8,000$ $\mathrm{Hz}$ 의 각 주파수별 기도 및 골도 청력역치를 측정하였다. 셋째, 어음 청력검사(speech audiometry)를 통하여 어음청취역치를 측정하였 다. 어음청취역치 검사에서 사용하는 어음은 일상생활에서 많이 사용하는 어휘 중에서 2 음절 단어로서, 양 음절의 강세가 동일한 양양격단어(spondaic word)를 사용한다. 검사자가 제시하는 검사 단어의 $50 \%$ 를 피검자가 정확하게 반복할 수 있는 검사 어음의 최 저 강도 $(\mathrm{dB})$ 를 피검자의 어음청취역치로 정의한다. 또한 피검자가
가장 편안하게 느끼는 검사 어음 강도인 쾌적수준(most comfortable loudness level)을 함께 측정하였다.

\section{언어적 기억력 검사}

서울언어학습검사를 통하여 언어적 기억력을 평가하였다. 검사 자는 피검자에게 꽃, 문구, 주방기구의 3 가지 범주에 속한 12 개의 단어를 2 초에 하나씩 불러준 후 기억하게 하는데, 기억 과제는 즉각 회상(immediate recall), 지연회상(delayed recall), 재인(recognition)의 세 가지로 이루어져있다. 먼저, 즉각회상 과제에서 피검자 는 단어들을 들은 직후 기억나는 단어들을 순서에 상관없이 모두 다시 말하도록 되어 있으며, 이를 3 회 반복 시행한다. 3 회 반복 시행 에서 정확하게 기억한 단어들을 합하여 즉각회상 점수를 산출한 다(만점 36점). 다음으로, 지연회상 과제는 즉각회상의 3 차 시행이 끝난 후 20 분이 경과한 뒤 시행한다. 피검자는 즉각회상 과제 시에 들었던 12 개의 단어들을 최대한 기억나는 대로 모두 말한다(만점 12점). 마지막으로, 재인검사에서 피검자는 검사자의 질문(예: “제 가 불러드린 것 중에 $\bigcirc \bigcirc$ 이 있었습니까?”)에 대해 ‘예/아니오'로 대답한다.

\section{소음 상황에서의 말소리 지각 검사}

한국어음청력검사(Korean Speech Audiometry, KSA; Lee et al., 2010)의 한국표준문장표(Korean Standard-Sentence Lists for Adults, KS-SL-A)를 사용하여 말소리 지각 능력을 평가하였다. 한국표준 문장표는 총 8 개의 목록이 있으며, 각 목록은 10 개의 문장(예: 버스 에 사람이 많아서 내가 앉을 자리가 없다) 및 총 40 개의 핵심 단어 (keywords)(예: “버스", “사람”, “많아서”, “앉을”, “자리”, “없다”) 로 구성되어 있다. 10 개의 문장은 최소 2어절(예: 옷이 크다)에서 최 대 7 어절(앞의 예 참조)로 최소 2 개에서 최대 6 개의 핵심 단어를 포 함한다. 총 8 개의 목록은 문장 구조 및 길이, 어휘 친밀도, 음소 빈 도와 분포, 주파수 특성 측면에서 모두 균등하다(Jang et al., 2008). 문장표는 표준어를 구사하는 남자 성우의 목소리로 $\mathrm{CD}$ 음원이 제 작되어 있어 말소리 지각 능력 검사 시에 청력검사기와 연결하여 활 용할수 있다는 장점이 있다.

말소리 지각 검사는 방음실에서 실시되었다. 문장표의 $\mathrm{CD}$ 음원 을 청력검사기(GSI 61, Grason-Stadler, Inc.)와 연결하여 문장 자극 을 제시하였고, 자극과 함께 제시되는 소음으로는 청력검사기의 차 폐음 중 하나인 어음소음(speech-spectrum noise)을 사용하였다. 어음소음이란 백색소음(white noise)을 회화음역대 주파수에 맞춰 필터링 한 소음이다(Katz, 2002). 피검자는 헤드폰(TDH-50, Telephonics Corp.)을 통하여 문장 자극 및 소음을 양측 귀로 동시에 
청취하였다. 문장 자극이 제시되는 강도는 각 피검자의 쾌적수준 으로 설정하였고, 소음이 제시되는 강도는 말소리와 소음이 같은 크기로 제시되는 SNR $0 \mathrm{~dB}$ 로 하였다. 검사자는 피검자에게 헤드 폰을 통해 제시되는 문장 자극을 끝까지 잘 듣고 따라 말하되, 전체 문장을 모두 정확하게 따라 말하지 못하더라도 들은 부분만큼 최 대한 따라 말할 수 있도록 지시하였다. 본 검사에 들어가기에 앞서 연습 문항을 통하여 피검자가 검사 방법을 제대로 이해하고 있는 지 확인하였다.

채점 방법은 다음과 같았다. 첫째, 40 개의 핵심 단어 중 피검자가 정확하게 따라 말한 단어의 총점을 백분율로 환산하여 말소리 지 각 능력을 평가하였다. 둘째, 각 문장의 첫 번째 핵심 단어에 해당 하는 10 개 단어 중 피검자가 정확하게 따라 말한 점수(만점 10점) 및 문장의 마지막 핵심 단어에 해당하는 10 개 단어 중 피검자가 정 확하게 따라 말한 점수(만점 10점)를 각각 측정하였다.

\section{통계 분석}

첫째, 집단 간 서울언어학습검사의 즉각회상 및 지연회상 점수, $\mathrm{SNR} 0 \mathrm{~dB}$ 에서의 말소리 지각 점수에 차이가 있는지 알아보기 위 하여 독립표본 $t$-검정을 시행하였다. 둘째, 말소리 지각 검사에서 문장 내 단어 위치에 따른 점수에 차이가 있는지 알아보기 위하여 반복측정 분산분석(repeated measures of ANOVA)을 실시하였다. 집단 간 요인(between-subjects factor)으로는 $\mathrm{aMCI}$ 및 정상 노년층 의 두 집단을 설정하였고, 집단 내 요인(within-subjects factor)으로 는 문장 내 핵심 단어의 위치(전반부, 후반부)를 설정하였다. 상호 작용 효과에 대한 사후분석으로서 본페로니 검정을 적용한 대응 별 비교 분석(pairwise comparison with Bonferroni correction)을

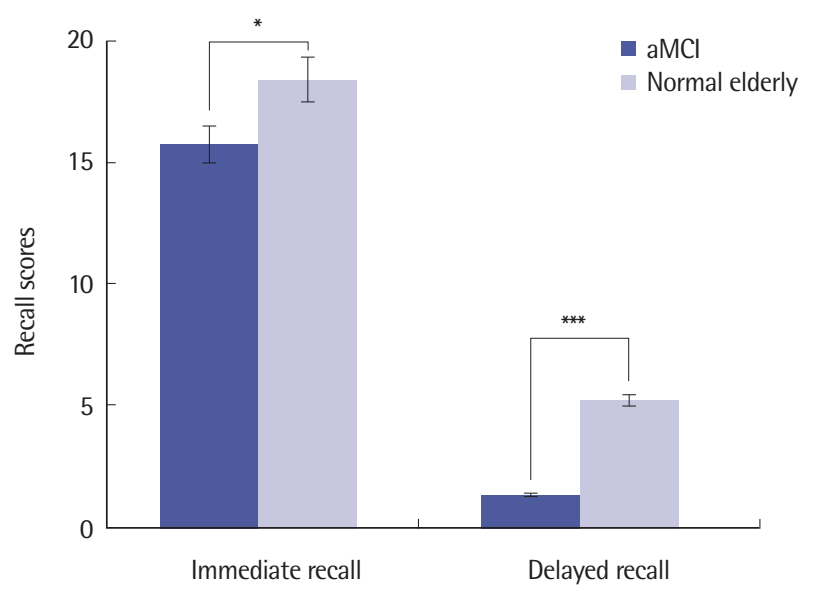

Figure 1. Comparison between amnestic mild cognitive impairment (aMCI) and normal elderly on immediate and delayed recall. ${ }^{*} p<.05,{ }^{* * *} p<.001$.
시행하였다. 통계적 분석은 SPSS version 21.0 (IBM) 프로그램을 사용하였으며, 유의수준은 .05 미만으로 설정하였다.

\section{연구 결과}

\section{서울언어학습검사 점수 비교}

서울언어학습검사의 즉각회상 과제에서 $\mathrm{aMCI}$ 노년층은 평균 $15.71 \pm 3.33$ 점을, 정상 노년층은 평균 $18.35 \pm 3.07$ 점을 획득하였 다. 한편, 지연회상 과제에서 $\mathrm{aMCI}$ 노년층은 평균 $1.35 \pm 1.59$ 점을, 정상 노년층은 평균 $5.21 \pm 1.71$ 점의 수행력을 보였다. 독립표본 $t$-검 정을 시행하여 집단 간 점수를 비교한 결과, 즉각회상 $(p<.05)$ 및 지연회상 $(p<.001)$ 과제에서 모두 $\mathrm{aMCI}$ 가 정상 노년층에 비해 유 의하게 낮은 수행력을 나타내어 언어적 기억력에 결함을 보였다 (Figure 1).

\section{$\mathrm{SNR} 0 \mathrm{~dB}$ 에서의 문장 지각 점수 비교}

$\mathrm{SNR} 0 \mathrm{~dB}$ 에서 문장 지각 과제를 시행한 결과, $\mathrm{aMCI}$ 노년층은 평 균 $77.67 \% \pm 16.71 \%$ 의 수행력을 보여, 정상 노년층의 평균 $85.71 \%$ $\pm 15.42 \%$ 와 유의한차이를 나타내지 않았다 $(p=.198$ ) (Figure 2).

\section{문장 내 핵심 단어 위치에 따른 점수 비교}

반복측정 분산분석을 시행한 결과, 집단(2요인: $\mathrm{aMCI}$ 노년층, 정 상 노년층 $) \times$ 문장 내 핵심 단어 위치(2요인: 전반부, 후반부)의 상호 작용 효과가 유의하였으며 $\left(F_{(1,26)}=10.452, p<.01\right)$, 문장 내 핵심 단 어 위치에 대한 주효과는 유의하나 $\left(F_{(1,26)}=48.670, p<.001\right)$ 집단에 대한 주효과는 유의하지 않았다 $\left(F_{(1,26)}=4.116, p=.053\right)$. 상호작용

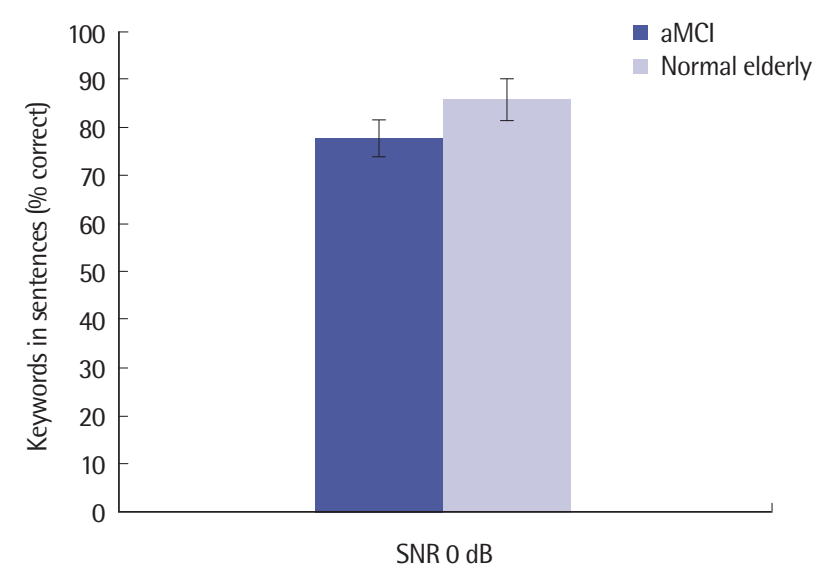

Figure 2. Comparison between amnestic mild cognitive impairment (aMCI) and normal elderly on sentence recognition. 


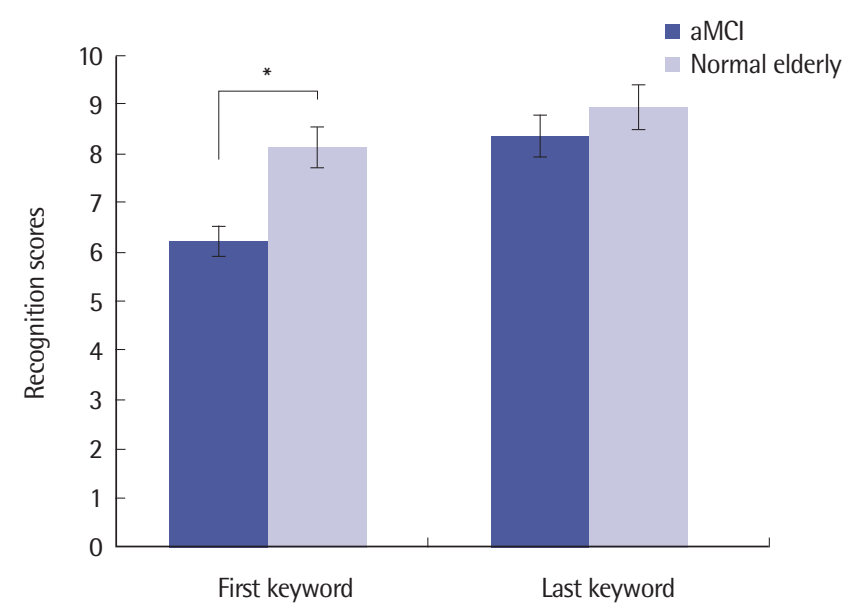

Figure 3. Comparison between amnestic mild cognitive impairment (aMCI) and normal elderly on sentence recognition according to keyword position. ${ }^{*} p<.05$.

효과에 대한 사후분석 결과, $\mathrm{aMCI}$ 노년층은 정상 노년층에 비해 문장 내 전반부 핵심 단어 지각에서 유의하게 낮은 점수를 나타내 었다 $(p<.05)$. 그러나 문장 내 후반부 핵심 단어 지각에서는 두 집 단 간 통계적으로 유의한 차이가 없었다 $(p=.329)$ (Figure 3).

\section{논의 및 결론}

일상생활 대화는 대부분 주변 소음 환경에서 이루어지며, 인지 능력에 결함이 있을수록 소음 상황에서 말소리를 올바르게 지각하 고 이해하는 능력이 저하되어 의사소통에 어려움을 겪는다. 소음 상황에서 청자는 문맥적 추론 등의 인지적 처리 과정을 통하여 왜 곡된 정보를 지속적으로 복구해야 하는 동시에 올바르게 지각한 정보는 계속 기억하고 있어야 한다. 이러한 인지적 처리량(cognitive processing load)이 청자의 인지적 용량(cognitive capacity)을 초과 하면 원활한 말소리 지각이 이루어지지 못하나, 제한된 인지적 용 량 내에서 인지적 과제들이 적절히 수행되면 말소리 지각 및 청각적 이해에 큰 어려움이 없다(Rönnberg et al., 2013). 이때, 주변 소음의 크기가 커질수록, 즉 SNR이 낮아질수록 인지적 처리량은 많아진 다(Rönnberg et al., 2010). 본 연구에서 aMCI가 정상 노년층에 비 하여 인지능력이 저하됨에도 불구하고 말소리 지각에 차이가 나타 나지 않은 것은, SNR $0 \mathrm{~dB}$ 의 소음 조건에서 필요한 인지적 처리량 이 $\mathrm{aMCI}$ 의 인지적 용량을 초과하지 않았기 때문으로 해석할 수 있 다. 그러나, $\mathrm{SNR}-5 \mathrm{~dB}$ 에 이르면 $\mathrm{aMCI}$ 노년층은 정상 노년층에 비 하여 말소리 지각 점수가 확연하게 낮아지는데(Lee et al., 2016), 이 는 $\mathrm{aMCI}$ 의 저하된 인지적 용량 내에서 말소리 지각에 필요한 인지 적 처리 과정들이 적절히 수행되지 못했기 때문이다.
선행 연구들에서 적용한 채점방식, 즉 정확하게 지각한 핵심 단 어를 모두 합산하여 말소리 지각을 평가하는 방식에는 지각한 정 보의 ‘양’만이 고려된 반면, 지각 ‘과정'은 고려되지 못하였다. 즉, 정 확하게 지각한 핵심 단어의 총점은 같을지라도 어떠한 책략을 사 용하여 어떠한 정보를 지각하였는지에 대해서는 추가적인 분석이 필요하다. 이에, 본 연구에서는 문장 내 핵심 단어의 위치에 따라서 두 집단 간 지각 점수에 차이가 있는지 살펴보았다. 그 결과, 문장의 후반부에 위치한 핵심 단어에서는 두 집단 간 차이가 나타나지 않 았지만, 문장의 전반부에 위치한 핵심 단어에서는 $\mathrm{aMCI}$ 가 정상 노 년층에 비해 뚜렷하게 낮은 점수를 보였다. 이러한 결과는 다음의 두 가지 측면에서 논의가 가능하다.

첫째, 기억 과정에서 나타나는 계열위치효과가 말소리 지각에도 반영된 것으로 볼 수 있다. $\mathrm{aMCI}$ 노년층은 정상 노년층에 비해 서 울언어학습검사의 즉각회상 및 지연회상 수행력이 모두 저하되어 언어적 기억력에 결함을 나타내었다. 이러한 기억력 결함은 계열위 치효과의 차이로 나타나는데, $\mathrm{aMCI}$ 는 초두효과가 낮고 최신효과 가 높은 반면(Cunha et al., 2012; Howieson et al., 2011; Moser et al., 2013), 정상 노년층은 초두효과와 최신효과 간에 유의한 차이가 없 다(Howieson et al., 2011). 즉, aMCI 노년층은 새로 학습한 단어를 장기기억으로 응고화(consolidation)하는 데 결함이 있기 때문에 최근에 제시된 정보는 잘 기억하는 반면, 초반에 제시된 정보에 대 한 기억은 저하된다. 이러한 기억 과정이 소음 상황에서의 말소리 지각에도 반영되어 문장의 전반부에 위치한 핵심 단어에 비해 후 반부에 위치한 핵심 단어를 더 많이 지각한 것으로 해석할 수 있다.

그러나 이러한 지각 특성을 계열위치효과만으로 설명하기에는 제한점이 있다. 일반적으로 초두효과는 주로 장기기억을 반영하고 최신효과는 단기기억을 반영하는데(Atkinson \& Shiffrin, 1968; Baddeley \& Hitch, 1993; Davelaar, Goshen-Gottstein, Ashkenazi, Haarmann, \& Usher, 2005), 문장의 전반부 핵심 단어 지각이 저하 되는 것을 장기기억 결함만으로 설명할 수 없다. 왜냐하면, 본 연구 의 지각 과제에 사용된 문장들은 최소 2 어절에서 최대 7 어절의 길 이로, 장기기억보다는 단기기억의 관여도가 높다. 다소 긴 문장이 라 하더라도 먼저 지각한 단어들은 단기기억 저장소(Atkinson \& Shiffrin, 1968)에 머물렀다가 인출된다. 이러한 측면에서, 문장 내 핵심 단어 위치에 따른 두 집단 간 수행력의 차이는 작업기억(working memory) 용량의 차이에도 기인한다. 작업기억이란 일시적으로 정보를 '저장(storage)'하고 '처리(processing)'하는 능력이다(Baddeley, 1992). 이는, 이미 지각한 정보를 기억(저장)하는 동시에 왜곡 되어 제시되는 소리에 대해서는 지속적으로 추론(처리)해야 하는 소음 상황에서의 말소리 지각에 중요하게 관여한다(Gordon-Salant 
\& Cole, 2016; Lee \& Kim, 2016). 일반적으로 aMCI는 정상 노년층 에 비하여 작업기억이 저하되는데(Choi, 2016; Economou, Papageorgiou, Karageorgiou, \& Vassilopoulos, 2007; Nordahl et al., 2005; Zheng et al., 2012), 제한된 작업기억 용량을 최대한 효율적 으로 사용하기 위한 기억 전략으로서 먼저 처리된 정보, 즉 시간적 으로 길게 저장해야 하는 정보는 기억에서 삭제하고 최근에 처리된 정보를 선택적으로 기억할 가능성이 있다. 이러한 전략은 주의 할 당(attention allocation) (Karatekin, Couperus, \& Marcus, 2004)의 개념으로 설명 할 수 있다. 소음 상황에서 말소리를 지각하는 과제 에는 주의력이 중요하게 관여하는데(Wild et al., 2012), 우선 청각 적 자극을 부호화(coding)하고 분석하는 지각적 처리(perceptual processing)에 관여한다(Awh, Vogel, \& Oh, 2006). 또한, 지각된 정 보들 가운데 작업기억으로 보내야 할 정보들을 선택(postperceptual selection)하게 되는데(Awh et al., 2006), Awh 등(2006)은 이를 “작업기억의 게이트키퍼(gatekeeper for working memory)"라는 개념으로 정의하였다. 이러한 측면에서 $\mathrm{aMCI}$ 노년층은 최근에 제 시된 정보의 지각적 처리 및 기억에 주의력의 많은 부분을 선택적 으로 할당한다.

둘째, $\mathrm{aMCI}$ 가 문장의 전반부에 비해 후반부 핵심 단어를 더 많 이 지각했다는 점은, 한국어 문장 구조의 특성상 문장의 서술어에 해당하는 내용을 더 잘 지각한 것으로도 해석 가능하다. 한국어에 서 서술어는 문장이 의미하는 바를 이해하는 데 있어서 핵심적인 역할을 담당하는데(An, Choi, Oh, \& Shin, 2010; Lee, 2001), 주로 문장의 마지막인 동사에 의미 초점이 위치한다(Park, 2012). 영어가 명사 중심의 언어인 반면에 한국어는 동사 중심의 언어로서, 영어 에서는 명사구로 이루어진 주어나 목적어가 쉽게 생략될 수 없다. 한편, 한국어에서는 명사구로 구성이 된 주어나 목적어가 상대적 으로 쉽게 생략되는 반면 동사 생략은 어렵다(Park, 2012). 이러한 한국어의 산출 특성은 한국어가 모국어인 청자가 말소리를 지각할 때에도 반영될 수 있는데, 왜냐하면 언어 고유(language-specific)의 산출 특성은 지각 특성과 밀접하게 연관되어 있기 때문이다(Diehl, Lotto, \& Holt, 2004). 예컨대, 영어는 음절의 경계가 모호한 언어인 반면 불어는 음절의 경계가 비교적 명확한 언어이다. 불어 원어민 청자는 말소리 지각 시에 분철법(syllabification) 전략을 사용하여 단어 이해의 효율성을 높이는 반면 영어 원어민 청자는 지각 과정 시에 이러한 분철법을 전략으로 활용하지 않는다(Cutler, Mehler, Norris, \& Segui, 1983). 이처럼 언어적 특성은 해당 언어 사용자의 지각에 영향을 미치는데, 즉, 한국어 청자는 서술어가 위치해있는 문장의 뒷부분에 더욱 집중하거나 이를 더 잘 지각하게끔 학습될 수 있다. 또한, 이렇게 학습된 지각 특성은 청자가 인지적 결함이 있
는 경우나 인지적 처리량이 증가된 과제에서 더욱 두드러진다. 다시 말해, 인지적으로 처리하거나 기억해야 할 양이 많아지는 경우에는 문장의 의미 이해에 있어서 중요한 후반부 서술어 지각에 선택적으 로 집중하게 될 가능성이 높은 것이다. 문장을 이해하기 위해서는 반드시 문장을 구성하는 모든 단어들의 의미를 파악하고 통합해야 만 하는 것은 아니다(Ferreira, Bailey, \& Ferraro, 2002; Kristensen, Wang, Petersson, \& Hagoort, 2013). 오히려 일상생활에서 일어나 는 많은 대화들 속의 문장 이해는 화자의 비유창함이나 주변 소음 등으로 인해 완전한 의미적 처리 과정을 거치기 어렵다. 그럼에도 불구하고, 청자는 문장 내에서 의미적, 문법적으로 강조되거나 핵 심이 되는 부분들에 주의를 기울여 이를 지각하고, 나아가 문장의 의미를 이해할 수 있다(Ferreira et al., 2002). 이때, 의미적, 문법적 으로 초점이 되는 부분이나 이를 강조하는 방식은 각 언어별로 차 이가 있다(Kristensen et al., 2013). Ferreira 등(2002)은 “충분한 문장 처리(good-enough sentence processing)"이라는 개념으로 이러한 문장 처리 과정을 설명하였다. 이러한 측면에서, $\mathrm{aMCI}$ 는 말소리 지 각의 효율성을 위해 의미 초점이 위치할 가능성이 높은 문장의 후 반부에 제한된 인지적 용량의 많은 부분을 할당할 수 있다. 이러한 논의는 한국어의 언어적 특성을 반영한 것으로, 향후 한국어 문장 성분을 주요 요인으로 한 말소리 지각 실험이 이루어진다면 더욱 구체적인 고찰이 가능할 것으로 본다.

이러한 연구결과는 인지장애 노년층의 의사소통 전략 및 중재 방향 설정에 있어서 중요하게 고려되어야 한다. 노년층의 청각적 이 해력은 인지능력과 관련성이 높은데(Choi, 2014), 구체적으로 언어 자극의 길이가 길어지거나 언어적 복잡성이 증가하는 등 인지능력 의 관여도가 커질수록 이해력은 더욱 저하된다(Lee, Lee, Song, \& $\mathrm{Kim}, 2014)$. 이에, 인지장애 노년층의 언어 이해를 촉진시키기 위한 보상 전략으로서, 의사소통 시에 언어 자극의 길이를 짧고 단순하 게 하기, 말 속도를 천천히 하기, 주변 환경 소음을 제거하기 등의 방 법이 제시되었다(Lee et al., 2014). 이와 더불어, 소음 상황에서의 대 화 시에는 핵심 단어를 문장의 후반부로 위치시키거나 문장의 마지 막에 한번 더 중요 내용을 강조하는 전략이 인지장애 노년층의 말 소리 지각 및 청각 이해력 향상을 위해 중요하게 고려되어야 할 것 으로 본다.

\section{REFERENCES}

Aimoni, C., Prosser, S., Ciorba, A., Menozzi, L., Soavi, C., \& Zuliani, G. (2014). Speech audiometry tests in noise are impaired in older patients with mild cognitive impairment: a pilot study. Journal of International Advanced Otol- 
ogy, 10, 228-233.

An, E. H., Choi, M. G., Oh, J. H., \& Shin, H. J. (2010). Semantic processing of Korean polysemous verbs in sentential context. Journal of Language Sciences, $17,103-125$.

Atkinson, R. C., \& Shiffrin, R. M. (1968). Human memory: a proposed system and its control processes. Psychology of Learning and Motivation, 2, 89-195.

Awh, E., Vogel, E. K., \& Oh, S. H. (2006). Interactions between attention and working memory. Neuroscience, 139, 201-208.

Baddeley, A. (1992). Working memory. Science, 255, 556-559.

Baddeley, A. D., \& Hitch, G. (1993). The recency effect: implicit learning with explicit retrieval? Memory \& Cognition, 21, 146-155.

Choi, H. J. (2014). Verbal working memory and verbal memory's relationship to discourse comprehension in healthy elderly. Communication Sciences \& Disorders, 19, 513-522.

Choi, H. J. (2016). Working memory and verbal memory's relationship to discourse comprehension in patients with amnestic mild cognitive impairment and with Alzheimer's disease. Communication Sciences \& Disorders, 21, 324-332.

Cunha, C., Guerreiro, M., de Mendonça, A., Oliveira, P. E., \& Santana, I. (2012). Serial position effects in Alzheimer's disease, mild cognitive impairment, and normal aging: predictive value for conversion to dementia. Journal of Clinical and Experimental Neuropsychology, 34, 841-852.

Cutler, A., Mehler, J., Norris, D., \& Segui, J. (1983). A language-specific comprehension strategy. Nature, 304, 159-160.

Davelaar, E. J., Goshen-Gottstein, Y., Ashkenazi, A., Haarmann, H. J., \& Usher, M. (2005). The demise of short-term memory revisited: empirical and computational investigations of recency effects. Psychological Review, 112, $3-42$.

Davis, M. H., \& Johnsrude, I. S. (2007). Hearing speech sounds: top-down influences on the interface between audition and speech perception. Hearing Research, 229, 132-147.

Diehl, R. L., Lotto, A. J., \& Holt, L. L. (2004). Speech perception. Annual Review of Psychology, 55, 149-179.

Economou, A., Papageorgiou, S. G., Karageorgiou, C., \& Vassilopoulos, D. (2007). Nonepisodic memory deficits in amnestic MCI. Cognitive and Behavioral Neurology, 20, 99-106.

Ferreira, F., Bailey, K. G., \& Ferraro, V. (2002). Good-enough representations in language comprehension. Current Directions in Psychological Science, 11, 11-15.
Friederici, A. D. (2012). The cortical language circuit: from auditory perception to sentence comprehension. Trends in Cognitive Sciences, 16, 262-268.

Gates, G. A., Anderson, M. L., Feeney, M. P., McCurry, S. M., \& Larson, E. B. (2008). Central auditory dysfunction in older persons with memory impairment or Alzheimer dementia. Archives of Otolaryngology-Head \& Neck Surgery, 134, 771-777.

Gates, G. A., Gibbons, L. E., McCurry, S. M., Crane, P. K., Feeney, M. P., \& Larson, E. B. (2010). Executive dysfunction and presbycusis in older persons with and without memory loss and dementia. Cognitive and Behavioral Neurology, 23, 218-223.

Glanzer, M., \& Cunitz, A. R. (1966). Two storage mechanisms in free recall. Journal of Verbal Learning and Verbal Behavior, 5, 351-360.

Gordon-Salant, S., \& Cole, S. S. (2016). Effects of age and working memory capacity on speech recognition performance in noise among listeners with normal hearing. Ear and Hearing, 37, 593-602.

Howieson, D. B., Mattek, N., Seeyle, A. M., Dodge, H. H., Wasserman, D., Zitzelberger, T., \& Jeffrey, K. (2011). Serial position effects in mild cognitive impairment. Journal of Clinical and Experimental Neuropsychology, 33, 292-299.

Idrizbegovic, E., Hederstierna, C., Dahlquist, M., Nordström, C. K., Jelic, V., \& Rosenhall, U. (2011). Central auditory function in early Alzheimer's disease and in mild cognitive impairment. Age and Ageing, 40, 249-254.

Jang, H. S., Lee, J. H., Lim, D. H., Lee, K. W., Jeon, A. R., \& Jung, E. J. (2008). Development of Korean Standard Sentence Lists for sentence recognition test. Audiology, 4, 161-177.

Kang, Y. (2006). A normative study of the Korean-Mini Mental State Examination (K-MMSE) in the elderly. Korean Journal of Psychology: General, $25,1-12$.

Kang, Y., \& Na, D. L. (2003). Seoul Neuropsychological Screening Battery. Incheon, Korea: Human Brain Research \& Consulting Co.

Karatekin, C., Couperus, J. W., \& Marcus, D. J. (2004). Attention allocation in the dual-task paradigm as measured through behavioral and psychophysiological responses. Psychophysiology, 41, 175-185.

Katz, J. (2002). Handbook of clinical audiology (5th ed.). Philadelphia, PA: Lippincott Williams \& Wilkins.

Kristensen, L. B., Wang, L., Petersson, K. M., \& Hagoort, P. (2013). The interface between language and attention: prosodic focus marking recruits a general attention network in spoken language comprehension. Cerebral Cortex, 23, 1836-1848.

Lee, C. K. (2001). A study on structures of semantic features according to the 
analysing levels of Korean verbs. Korean Semantics, 8, 133-170.

Lee, J. H., Cho, S. J., Kim, J. S., Jang, H. S., Lim, D. H., Lee, K. W., \& Kim, H. J. (2010). Korean speech audiometry (KSA). Seoul: Hakjisa.

Lee, S. J., \& Kim, H. (2016). Speech perception difficulties and their associated cognitive functions in older adults. Journal of the Korean Society of Speech Sciences, 8, 63-69.

Lee, S. J., Lee, S. J., Song, J. Y., \& Kim, H. (2014). Characteristics of language comprehension in normal elderly and the mild cognitive impaired. Dementia and Neurocognitive Disorders, 13, 51-62.

Lee, S. J., Park, K. W., Kim, L. S., \& Kim, H. (2016). Effects of noise level and cognitive function on speech perception in normal elderly and elderly with amnestic mild cognitive impairment. Cognitive and Behavioral Neurology, 29, 68-77.

Moser, B., Deisenhammer, E. A., Marksteiner, J., Papousek, I., Fink, A., \& Weiss, E. M. (2013). Serial position effects in patients with mild cognitive impairment and early and moderate Alzheimer's disease compared with healthy comparison subjects. Dementia and geriatric Cognitive Disorders, 37, 19-26.

Murdock, B. B. (1962). The serial position effect of free recall. Journal of Experimental Psychology, 64, 482-488.

Nordahl, C. W., Ranganath, C., Yonelinas, A. P., DeCarli, C., Reed, B. R., \& Jagust, W. J. (2005). Different mechanisms of episodic memory failure in mild cognitive impairment. Neuropsychologia, 43, 1688-1697.

Park, C. H. (2012). Statistical approach about ellipsis of Korean and English. Journal of the Society of Korean Language and Literature, 66, 171-191.

Petersen, R. C., Doody, R., Kurz, A., Mohs, R. C., Morris, J. C., Rabins, P. V., ... \& Winblad, B. (2001). Current concepts in mild cognitive impairment. Archives of Neurology, 58, 1985-1992.
Pichora-Fuller, M. K. (2006). Audition and cognition: what audiologists need to know about listening. In R. C. Seewald \& C. V. Palmer (Eds.), Hearing care for adults (pp. 71-85). Chicago, IL: Phonak AG.

Rahman, T. T. A., Mohamed, S. T., Albanouby, M. H., \& Bekhet, H. F. (2011). Central auditory processing in elderly with mild cognitive impairment. Geriatrics \& Gerontology International, 11, 304-308.

Rönnberg, J., Lunner, T., Zekveld, A., Sörqvist, P., Danielsson, H., Lyxell, B., ... \& Rudner, M. (2013). The Ease of Language Understanding (ELU) model: theoretical, empirical, and clinical advances. Frontiers in Systems Neuroscience, 7, 1-17.

Rönnberg, J., Rudner, M., Lunner, T., \& Zekveld, A. A. (2010). When cognition kicks in: working memory and speech understanding in noise. Noise and Health, 12, 263-269.

Tun, P. A., Benichov, J., \& Wingfield, A. (2010). Response latencies in auditory sentence comprehension: effects of linguistic versus perceptual challenge. Psychology and Aging, 25, 730-735.

Wild, C. J., Yusuf, A., Wilson, D. E., Peelle, J. E., Davis, M. H., \& Johnsrude, I. S. (2012). Effortful listening: the processing of degraded speech depends critically on attention. Journal of Neuroscience, 32, 14010-14021.

Wingfield, A., McCoy, S. L., Peelle, J. E., Tun, P. A., \& Cox, C. L. (2006). Effects of adult aging and hearing loss on comprehension of rapid speech varying in syntactic complexity. Journal of the American Academy of Audiology, 17, 487-497.

Zheng, D., Dong, X., Sun, H., Xu, Y., Ma, Y., \& Wang, X. (2012). The overall impairment of core executive function components in patients with amnestic mild cognitive impairment: a cross-sectional study. BMC Neurology, 12, $1-10$. 


\section{국문초록}

\section{경도인지장애에서 문장 내 핵심 단어 위치에 따른 말소리 지각}

이수정' 김향희 ${ }^{12}$

${ }^{1}$ 연세대학교 대학원 언어병리학협동과정, ${ }^{2}$ 연세대학교 의과대학 재활의학교실 및 재활의학연구소

배경 및 목적: 말소리 지각(speech perception)은 청각적 언어 이해에 선행되는 필수적인 언어처리과정으로서, 청자의 청력뿐만 아니라 기억 등의 인지능력의 영향을 받으며, 특히 경도인지장애의 경우는 더욱 그러하다. 이에, 본 연구에서는 경도인지장애에서 소음 상황에 서의 말소리 지각이 문장 내 핵심 단어의 위치에 따라 차이가 있는지 알아보았다. 방법: 경도인지장애 노년층 14 명 및 대조군인 정상 노 년층 14 명, 총 28 명을 대상으로 즉각회상 및 지연회상 과제와 문장 지각 과제를 실시하였다. 결과: 경도인지장애 노년층은 정상 노년층 에 비하여 즉각회상 및 지연회상이 모두 저하되어 기억력 결함을 나타내었다. 또한, 경도인지장애 노년층이 정상 노년층에 비하여 저하 된 말소리 지각 수행력을 보인 부분은 문장의 전반부에 위치한 핵심 단어에서였다. 논의 및 결론: 본 결과는 경도인지장애의 예측치로 보고된 바 있는 계열위치효과 중 낮은 초두효과(primacy effect)가 말지각 과정에서도 반영된다는 것을 확인해주었다. 경도인지장애군 은 저하된 작업기억을 효과적으로 사용하기 위한 전략으로서 최근 지각한 정보만을 선택적으로 저장할 가능성이 있으며, 한국어 문장 이해에 중요한 서술어 지각에 더욱 집중할 가능성이 있다. 인지장애 노년층의 말지각 및 청각 이해력 향상을 위한 전략으로서 핵심 단 어를 문장의 후반부로 위치시키거나 문장의 마지막에 한번 더 중요 내용을 강조하는 방안이 제시될 수 있다.

핵심어: 경도인지장애, 말소리 지각, 계열위치효과, 작업기억, 한국어 문장 이해

\section{참고문헌}

강연욱(2006). K-MMSE (Korean-Mini Mental State Examination)의 노인 규준 연구. 한국심리학회지: 일반, 25, 1-12. 강연욱, 나덕렬(2003). 서울신경심리검사(Seoul Neuropsychological Screening Battery). 인천: 휴브알엔씨.

박청희(2012). 한국어와 영어의 생략 현상에 대한 통계적 접근. 어문논집, 66, 171-191.

안은혜, 최민경, 오지향, 신현정(2010). 문장맥락에서 한국어 다의동사의 의미처리. 언어과학, 17, 103-125.

이수정, 김향희(2016). 노년층의 말소리 지각 능력 및 관련 인지적 변인. 말소리와 음성과학, 8, 63-69.

이수정, 이승진, 송지연, 김향희(2014). 정상 노년층과 경도인지장애의 언어 이해력 특성. 대한치매학회지, 13, 51-62.

이정학, 조수진, 김수진, 장현숙, 임덕환, 이경원, 김형종(2010). 어음청각검사(Korean speech audiometry). 서울: 학지사.

이찬규(2001). 문장 의미 해석을 위한 한국어 동사의 층위별 의미 자질 구조화. 한국어의미학, 8, 133-170.

장현숙, 이정학, 임덕환, 이경원, 전아름, 정은조(2008). 문장인지검사를 위한 한국 표준 문장표 개발. 청능재활, 4, 161-177.

최현주(2014). 고령자의 담화 이해 능력과 구어 작업기억 및 언어기억과의 상관. 언어청각장애연구, 19, 513-522.

최현주(2016). 기억상실형 경도인지장애와 알츠하이머병 환자의 이야기 이해 능력과작업기억 및 언어기억의 상관. 언어청각장애연구, 21, 324-332. 